YIYYECEK İÇECEK İŞLETMELERINDE SOSYAL MEDYA KULLANIMI VE KRİZ YÖNETIMİ Social Media Usage and Crisis Management in Food and Beverage Businesses

* Hülya TAŞTAN

** Enes GÜRHANI

\section{cos Tiproun}

doi.org/10.32958/gastoria.587237

Yazar Bilgileri

\section{ORCID:}

*0000-0003-1190-2758

** 0000-0003-2619-2525

Email:

*hulyatastan@yahoo.com

** enesgurhani@gmail.com

\section{ÖZET}

Günümüzde insanlar artık zamanlarını çoğunu sosyal medyada geçirmektedir. Hızla gelişen bu pazarla birlikte insanlar daha önceki yıllara göre daha hızlı bir şekilde memnuniyetlerini veya şikayetlerini dile getirebilir bir duruma gelmişlerdir. Sosyal medyanın bu kadar yaygın kullanılan bir araç haline gelmesi ve doğabilecek yanlış bilgilerin yayılmasının engellenememesi nedeni ile çeşitli krizlerin yaşanması da kaçınılmaz olmaktadır. Yapılan bu çalışma ile yiyecek içecek işletmelerinin karşılaştıkları olumsuz olayların nasıl sosyal medyada kriz haline gelebildiği ve bu krizlerin nasıl yönetildiği belirlenmeye çalışılmıştır. Bu bağlamda yapılan örnek olay incelemesi ile yedi yiyecek içecek işletmesinin karşılaşıtı̆ı sosyal medya krizleri incelenmiştir. Sonuç olarak bu krizlerin işletmenin kendisinden veya dış etmenlerden kaynaklanabileceği tespit edilmiştir.

Anahtar Kelimeler: Sosyal medya, kriz, kriz yönetimi, internet

\section{ABSTRACT}

Nowadays, people spend most of their time on social media. With this rapidly developing market, people have been able to express their satisfaction or complaints more quickly than in previous years. It is inevitable that there will be various crises due to the fact that social media has become such a widely used tool and the spread of false information cannot be prevented. With this study, it has been tried to determine how the negative events faced by food and beverage enterprises can become crisis in social media and how these crises are managed. In this context, the case study examined the social media crises faced by seven food and beverage businesses. As a result, it has been determined that these crises may be caused by the enterprise itself or external factors.

Keywords: Social media, crisis, crisis management, internet 


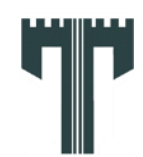

Gastroia: Journal of Gastronomy and Travel Research, Vol. 3, Issue 4 (Özel Sayı), 612-623, 2019

Yiyecek İçecek İşletmelerinde Sosyal Medya Kullanımı ve Kriz Yönetimi Hülya TAŞTAN, Enes GÜRHANI

\section{GíRiş}

Küreselleşme ile birlikte ulusal sınırların önemini yitirmesi ve her daim ulaşılabilir olmanın öneminin artması ile birlikte internet kullanımı yaygınlaşmıştır. Böylelikle uluslararasılaşma kolaylaşmış ve haberleşme daha yaygın hale gelmiştir (Mathews, Bianchi, Perks, Healy, \& Wickramasekara, 2016, s. 820). Günümüz koşullarında insanlar, internet üzerinden haberleşmekte ve mesajlaşabilmektedirler. Aynı zamanda günlük yaşantılarında karşılaş̧ıkları ekonomik, sosyal ve kültürel sorunları başkalarına aktarabilmekte, yaşadıklarını üçüncü kişilere ulaştırabilmektedirler. Son zamanlarda internet ağızdan ağıza iletişimlerin yaşandığı bir ortam haline gelmiştir. (Gülmez, 2011, s. 31)

Ortalama yirmi yıllık ömrü olmasına rağmen internetin gündelik yaşantımızdaki yeri oldukça fazladır. Birkaç yıl öncesine kadar sadece "internet" sonrasında ise "sanal âlem" sözcükleri ile anılan bu yeni iletişim aracının telaffuzuna sosyal medya sözcüğü de eklenmiştir (Oğuz, 2012, s. 1159). İnsanlar sosyal medya ve diğer birçok çevrimiçi uygulama sayesinde, birbirleri ile iletişim kurup, istedikleri bilgiye ulaşabilir hale gelmiştir. İnstagram, facebook, snapchat ve twitter gibi sosyal medya programları, programlayıcıları tarafından sürekli güncel tutulan ve geniş kitlelere ulaşma potansiyeli olan sistemlerdir (Capatani, Micu, Micu, Bouzaabia, \& Bouzaabia, 2018). Örneğin bu programları kullanan yiyecek ve içecek işletmeleri, sosyal medya üzerinden müşterilerine sundukları hizmetler ve ürünlerinin reklamlarını daha hızlı ve daha geniş kitlelere ulaştrabilmektedirler. Bu sayede işletmeler reklam giderlerini azaltabilmekle birlikte zamandan ve personelden de kazanç sağlayabilmektedirler. Dolayısıyla da piyasada rekabet avantajı elde etmiş olmaktadırlar.

İşletmeler sosyal medya ile geniş kitlelere ulaşabiliyorken, müşterileri de bu işletmelerde yaşadıkları sorunları ve şikâyetleri geniş kitlelere ulaştırarak işletmelerin kriz yaşamasına sebep olabilmektedirler. Sosyal medyanın kontrol dışı yayılma potansiyelinden dolayı oluşabilecek en ufak bir kriz bile çok hızlı bir şekilde büyüyerek sorun haline gelebilmektedir. Kimi yiyecek içecek işletmeleri bu krizi başarı ile yönetirken kimi işletmeler ise krize yenik düşerek çeşitli sıkıntılar içerisine girmektedir (Capatani, Micu, Micu, Bouzaabia, \& Bouzaabia, 2018). Diğer bir deyişle işletmelerin yaşadıkları sosyal medya krizleri muhtemel bir iflas ve kapanma sebebi olabilmektedir.

\section{KAVRAMSAL ÇERÇEVE}

$\mathrm{Bu}$ bölümde öncelikle günümüzde kullanımı gittikçe yaygınlaşan sosyal medya kavramı ile ilgili bilgi verilmeye çalışılmıştır. Devamında kriz ve kriz yönetimi kavramları açıklanmıştır.

\section{Sosyal Medya Kavramı}

Sosyal medya, bilginin açığa çıkmasını, aktarılmasını, tüketilmesini sağlayan, ulaşılabilir bir iletişim ortamı oluşturan, kullanıcıların deneyimlerini paylaşmalarında kullandıkları bir kitle iletişim aracı olarak bilinmektedir (Sotiriadis , 2016; Leung, Law, Hoof, \& Buhalis, 2013; Zeng \& Gerritsen, 2014; Hossein, ve diğerleri, 2015; Capatina, Micu, Micu, Bouzaabia, \& Bouzaabia, 2017). Başka bir tanımda ise sosyal medyanın ne olduğundan şöyle bahsedilmiştir; sosyal medya en fazla paylaşımın sağlandığı, online medyanın yeni bir türü olarak firsatların sağlandığı yeni fikirlerden biridir (Mayfield, 2010). Bu tanımların 
Yiyecek İ̧ecek İsletmelerinde Sosyal Medya Kullanımı ve Kriz Yönetimi Hülya TAŞTAN, Enes GÜRHANI

yanı sıra Weber'e (2009) göre; ortak ilgiye sahip insanların düşüncelerini, yorumlarını ve fikirlerini aktardıkları sanal ortam, sosyal medya olarak tanımlanmıştır.

İngilizce' de "gossip" olarak ifade edilen söylenti ve ağızdan ağıza iletişim şeklinde de kullanılabilen dedikodu kavramı, internet uygulamalarının yaygınlaşması ile yeni bir boyut kazanmıştır (Sarışık \& Özbay, 2012). Sosyal medya en yüksek derecede paylaşımın gerçekleştiği ve yeni firsatların doğduğu online medyanın yeni bir türüdür (Vural \& Bat, 2010, s. 3351-3352).

Sosyal medyanın özellikleri şu şekilde sıralanabilir; her katılımcıya açıktır, katılımcılarını kendilerini istedikleri gibi ifade etme konusunda cesaretlendirir, ilgili olan her bir kullanıcıdan hızlı bir şekilde geri bildirim alır. Geleneksel medya sadece yayın yapmaya ilişkin yani sadece içerik aktarımı ve dinleyiciye bilgi aktarımından sorumlu iken sosyal medyada iki yönlü iletişim sağlayabilmektedir. Topluluklar da bu iki yönlü iletişim sayesinde, sevdikleri fotoğraf, politik değerler, favori TV şovları gibi ilgili oldukları şeyleri birbirleri ile paylaşabilmektedir (Vural \& Bat, 2010). Diğer bir açıdan, daha önceki yıllarda kişiler aldıkları çeşitli hizmetlerden, bu hizmetleri sağlayan üretici firmaların marka yüzlerinden ve bu markaların meydana getirdiği ürünlerden yakın çevreleri ile yaptıkları sohbetler esnasında bahsederken. Günümüzde sosyal medyanın gelişmesi ile bu sohbet daha geniş kitlelere yayılarak sohbet odalarında yapılan çevrimiçi sohbetler, gönderi altına yazılan memnuniyet veya memnuniyetsizlik belirten yorumlar gibi yöntemlerle çok daha geniş kitlelerle paylaşılmaya başlanmıştır (Aydın, 2016, s. 1).

Market Tools' un (2011) araştırmasına göre, müşterileri sosyal medyada memnuniyetlerini veya memnuniyetsizliklerini belirten paylaşımlar yapan işletmelerin oranı \%34'tür. Buna karşın müşterileri herhangi bir geri bildirim yapmayan işletmelerin oranı ise \%44'tür. Araştırmaya katılan işletmelerin \%22'sinin müşterilerinin herhangi bir sosyal medya ile ilişkisi olmadığı tespit edilmiştir. Yine aynı araştırma içerisinde, işletmelerin Twitter ve Facebook üzerinden sağladıkları olumlu veya olumsuz geri bildirimlere, cevap verip vermedikleri incelenmiştir. Facebook üzerinden aldıkları geri bildirimlere işletmelerin sadece \%14'ü hiçbir zaman geri dönüş yapmadıklarını belirtirken, twitter üzerinden aldıkları geri bildirimlere işletmelerin \%24'ü hiçbir zaman geri dönüş yapmadıkları cevabını verdikleri sonucuna ulaşılmıştır. Bu oranlar hem müşteriler hem de işletmeler açısından sosyal medyanın etkin bir şekilde kullanılmaya başlandığını göstermektedir (Demirel, 2013, s. 27-28).

Türkiye'de ve Dünyada 2018 yılı sosyal medya ve internet kullanımı ile ilgili Kanca Medya'nın yayınladığı araştırma bulgularına göre Youtube kullanıcılarının sayısı 1,5 milyarı geçmiş durumdadır. Dünya genelinde ise aktif olarak İnstagram kullanıcısı 800 milyondur. Bu platforma her gün 95 milyon kadar fotoğraf ve kısa videolar yüklenmektedir. Aktif olarak kullananların yaş ortalaması ise $\% 90$ oranla 35 yaş altı olarak saptanmıştır. Diğer sosyal medya kullanıcıların sayısı ise şu şekildedir; Facebook 2,234 milyar, WhatsApp 1,5 milyar, Messenger 1,3 milyar ve Tumblr 794 milyon (Yeni Mesaj, 2018, 26.12.2018 tarihinde alınmıştır).

İstanbul Bilgi Üniversitesinin sosyal medyada markalar araştırmasına göre, araştırmaya katılanların \%70' e yakın bölümü sosyal medya üzerinden en az bir marka takip 
Yiyecek İ̧ecek İsletmelerinde Sosyal Medya Kullanımı ve Kriz Yönetimi Hülya TAŞTAN, Enes GÜRHANI

etmektedir. Bu oran içerisinde ise $\% 31,7^{\prime}$ 'si 1 ile 3 marka, \%20' si 4 ile 7 marka, \%13,4'ü 7 ile 10 marka ve \%3,4' ü ise 10'dan fazla markayı takip ettiklerini söylemişlerdir (Farajova, 2017). Yine aynı araştırmadan çıkarılan başka bir sonuca göre ise, sosyal medyada yayınlanan içerikler satın alma üzerinde çok fazla etkiye sahiptir. Araştırma göstermiştir ki, \%82,8 oranında etkileme şiddeti farklı seviyelerde de olsa satın alma üzerinde sosyal medyanın etkisi olduğu görülürken, olumsuz kampanyalardan etkilendiğini söyleyen kullanıcıların ortalamayı \%91,7'ye çıkardığı görülmüştür (Farajova, 2017). Bu oranlar dikkate alındığında artık işletmelerin pazarlama faaliyetleri için sosyal medyayı kullanmaya başlaması kaçınılmaz hale gelmektedir (Sü Eröz \& Doğdubay, 2012, s. 27).

\section{Kriz ve Kriz Yönetimi}

İşletmeler, varlıklarını sürdürdükleri müddetçe çeşitli kriz durumlarıyla karşılaşabileceklerdir. Kriz, öngörülmeyen, kısa sürede müdahale gerektiren ve işletme içerisindeki normal işleyişi bozan bir durumdur (Sezgin, 2003, s. 194). Kriz, birçok faktörden meydana gelmiş olabilir. Ortaya çıkmadan önce krizler çeşitli sinyaller verir ve buradaki en önemli nokta ise bu durumu en hızlı bir şekilde analiz edip gerekli önlemlerin alınmasıdır (Karaköse, 2007, s. 13). Krize karşı önlem alabilmek için krizi iyi yönetecek bir yönetim becerisi ve yönetim planlaması gerekmektedir. Kriz yönetim becerisi, ortaya çıkabilecek bir kriz durumunda zararı en alt seviyede tutarak, olası diğer krizlere karşı tedbir alınmasına yardımcı olur (Sezgin, 2003, s. 194).

Oteller üzerine yapılan bir krizi tahmin etme oranları araştırmasında, yöneticilerin önceden krizi tahmin etme oranları arasında gözle görülür bir fark bulunmamıştır. Genel müdür seviyesindeki bir yöneticinin krizi tahmin etme yüzdeleri daha yüksekken $(\% 46,4)$, müdür yardımcılarında $(\% 33,3)$, işletme sahiplerinde $(\% 28,6)$ ve ön büro şeflerinde $(\% 0)$ gerileme göstermiştir. Bu duruma sebep olarak, genel müdür seviyesindeki bir yöneticilerin büyük çoğunluğunun iyi eğitim aldığı ve alanında profesyonel olduğu gözlemlenirken, müdür yardımcısı, işletme sahibi ve diğer elemanlar içerisinde sırasıyla deneyimsiz oldukları, yeterli eğitimi almamaları ve iş yerlerinde henüz çok toy oldukları gözlemlenmiştir (Asunakutlu, Safran, \& Tosun , 2003, s. 150).

Kriz yönetimi, var olması muhtemel kriz durumlarını önceden tahmin edip, kaybı en az seviyede tutmak için gerekli çalışmaların yapılmasıdır (Bat \& Turan Yurtseven, 2014, s. 205). Yönetimin esnekliği ve haberleşmenin güvenilir olması, kriz yönetiminin olumlu sonuçlanması ve krizin yaşandığı dönemde, işletmenin halkın güvenini kazanması önemli bir etkendir. Etkili bir kriz yönetimi planı, medya, toplumsal ilişkiler ve işletmenin kriz anındaki savunmalarını destekler nitelikte olmalıdır (Khodarahmi, 2009, s. 527). Kriz ortaya çıkıp işletme içerisindeki düzeni bozmaya başladığında, gerekli önlemlerin alınarak tekrar eski düzenin geri getirilmesi gerekmektedir. İşletmeyi kriz öncesi durumu geri döndürebilmek için yöneticilerin çeşitli önlemler alarak, benzer olayların tekrarlanması önlenmelidir.

Çoğu işletmede olduğu gibi yiyecek ve içecek işletmelerinde de kriz yönetiminde ilk seviye krizi önceden tespit ederek buna karşı önlemler almaktır. Önceden tespit edilen kriz sinyallerinden sonra ikinci seviye krize hazırlanmak ve krizi önlemek için yapılacak 
Yiyecek İ̧ecek Issletmelerinde Sosyal Medya Kullanımı ve Kriz Yönetimi Hülya TAŞTAN, Enes GÜRHANI

çalışmalardır. Yiyecek ve içecek işletmelerinde önlem ve hazırlık çalışmaları; kriz içerisinde olumsuzluğa düşmeyerek olumlu tutum sergileme, yöneticilerin kriz yönetimi için planlamalar yapma, kriz yönetimi için bir grup oluşturma, olası senaryoların belirlenmesi, belirlenen senaryolara uygun stratejilerin belirlenmesi, iletişim planı geliştirilmesi, personel eğitimi gibi konuları içermektedir (Ataman, 2001, s. 256). Yiyecek ve içecek işletmelerinin krizlere hazırlıklı olabilmesi için yöneticiler yönetim faaliyetlerini doğru kullanmalı ve aldıkları kararlar işletmenin lehine olması kriz yönetimi için elzemdir (Akgöz, 2007, s. 162).

Krizler, özellikle son zamanlarda tüketiciler arasında oldukça fazla kullanılan sosyal medya sayesinde işletmeleri son derece ağır bir şekilde etkileyebilmektedir. Hatta işletmelerin varlıklarını bile tehdit ettiği ifade edilebilmektedir. Sosyal medya, krizlerin daha hızlı bir şekilde ortaya çıkıp yayılmasına sebep olabiliyorken diğer bir yandan bu krizin daha hızlı bir şekilde kontrol altına alınmasına ve çözüme ulaştırılmasına da yardım edebilmektedir (Aslan , 2016, s. 517). İşletmelerin sosyal medyayı aktif olarak kullanmaları, onların daha fazla kitleye ulaşmalarına ve ulaştıkları bu kitlenin anlayışına, algısına ve dolayısıyla da işletmenin imajına olumlu etkilerde bulunmalarına olanak vermektedir (Ward, 2011, s. 3).

İşletmeler sosyal medyada faal durumdayken bir yandan işletme çıkarlarına uygun bir şekilde çalışma yürütürken, bir yandan da kriz durumundan doğan kaos ortamında yanlış anlaşılmaya sebebiyet vermeyerek ve kaos ortamından uzaklaşıp, gerilimi azaltıcı bir tavır sergilemelidirler (Aslan 2, 2016, s. 517). Kriz döneminde işletmelerin çoğu ya küçülmeye giderek kendilerini güvenceye alırlar ya da yerinde sayarak fazla bir faaliyet göstermezler. Bundan dolayı işletmeler bu kriz durumunu olağan bir durum olarak görmeleri ve faaliyetlerinden herhangi bir eksiltme yapmadan çalışmaya devam etmeleri gerekmektedir. Böyle zamanlarda krizi avantaja çevirmek işletme açısından çok önemlidir (Öztürk, 2010, s. 2)

Son 10 yılda sosyal medyanın değeri artmış ve artmaya devam etmektedir. Her statüden insanın sosyal medya ile bir bağlantısı bulunmaktadır. Bu durum ise işletmelerin sosyal medya ile bağlantılarının kopmaması ve sosyal medyada yürüttükleri işlerin kontrolünün yapılmasını zorunlu k1lmaktadır (Bat \& Turan Yurtseven, 2014, s. 218). Günümüzde tüketiciler, istedikleri markalara çeşitli yollarla ulaşım sağlaması, birçok olumlu sonuç yaratmasına rağmen müşteri sadakati kavramının tanımını değiştirmişlerdir. Bundan dolayı, müşteri sadakatinin devamını sağlamak için işletme yöneticileri sosyal medya yönetimine önem vermektedirler (Beliktay, 2013, s. 11).

\section{YÖNTEM}

$\mathrm{Bu}$ araştırmada ilk önce internet siteleri ve işletmelerin sosyal medya hesapları analiz edilmiştir. Daha sonra krize neden olan paylaşımlar incelenerek örnek oluşturan olaylar kayıt altına alınmıştır. Bu kayıtlar örnek olay incelemesi tekniği kullanılarak analiz edilmiştir. 


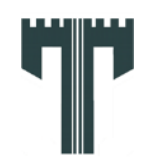

Gastroia: Journal of Gastronomy and Travel Research, Vol. 3, Issue 4 (Özel Sayı), 612-623, 2019

Yiyecek İçecek İsletmelerinde Sosyal Medya Kullanımı ve Kriz Yönetimi Hülya TAŞTAN, Enes GÜRHANI

\section{Bulgular}

Yaşanan çeşitli sosyal medya krizleri ve bu krizlerin kontrol altına alma çalışmaları şu şekilde sıralanabilir (medyasyon.wordpress.com, 2012);

Entenmann: Entenmann donut üreten bir firmadır. Kendi ürünlerin tanıtımlarını yapmak için twitter üzerinden suçlu değil anlamına gelen \#notguilty etiketini sosyal medya kullanıcılarına sunmuştur. Ama bu etiket o esnada şaibeli bir cinayet davası olan ve Casey Anthony davası olarak bilinen davanın twitter takipçileri tarafından da kullanılmaktadır. Sağduyu ile yaklaşılması gereken bir konu üzerinden reklam yapma kaygısı içerisinde bulunan firma çok fazla eleştiriye maruz kalınca, yapılan hatayı kabul ederek takipçilerinden ve eleştirenlerden özür diledi.

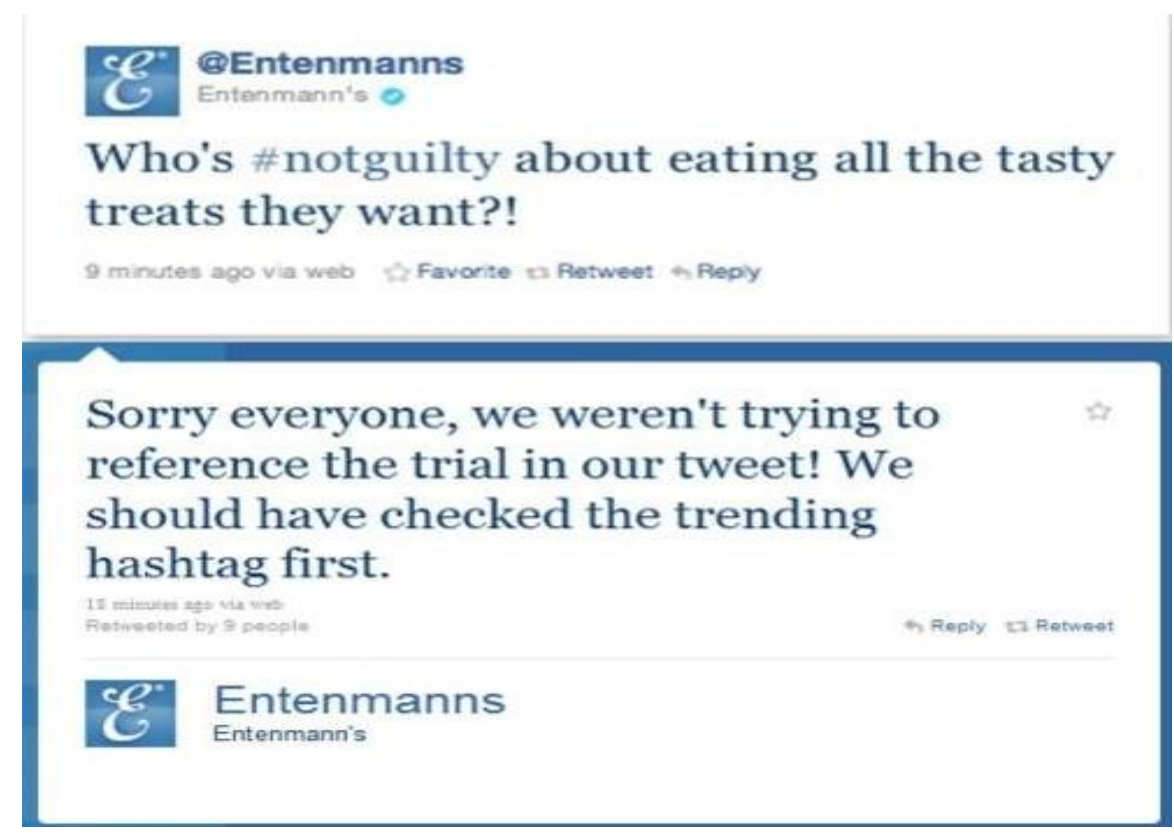

Şekil 2: Entenmann Firmasının Krize Neden Olan Sosyal Medya Paylaşımı (techcrunch.com, 2011)

Starbucks: Dünyaca ünlü içecek firması olan starbucks firmasının yaptı̆̆ hata ise şu şekilde ortaya çıkmıştır. Firma kendi içerisinde gerçekleşen çeşitli sorunlar nedeniyle orijinal sturbucks bardakları yerine Arjantin'de üretilen bardakları kullandıklarını söyleyerek müşterilerinden Arjantin bardağı kullandıkları için özür dilemişlerdir. Bu sosyal medya paylaşımı twitter kullanıcıları arasında hızla yayılarak, Arjantin vatandaşlarının verdiği tepkiyi geniş kitlelere yaymıştır. Oluşan bu büyük kriz, firma yetkilileri tarafindan resmi facebook sayfası üzerinden konu ile ilgili özür mesajı paylaşmasıyla kontrol altına alınmaya çalışılmıştır. 


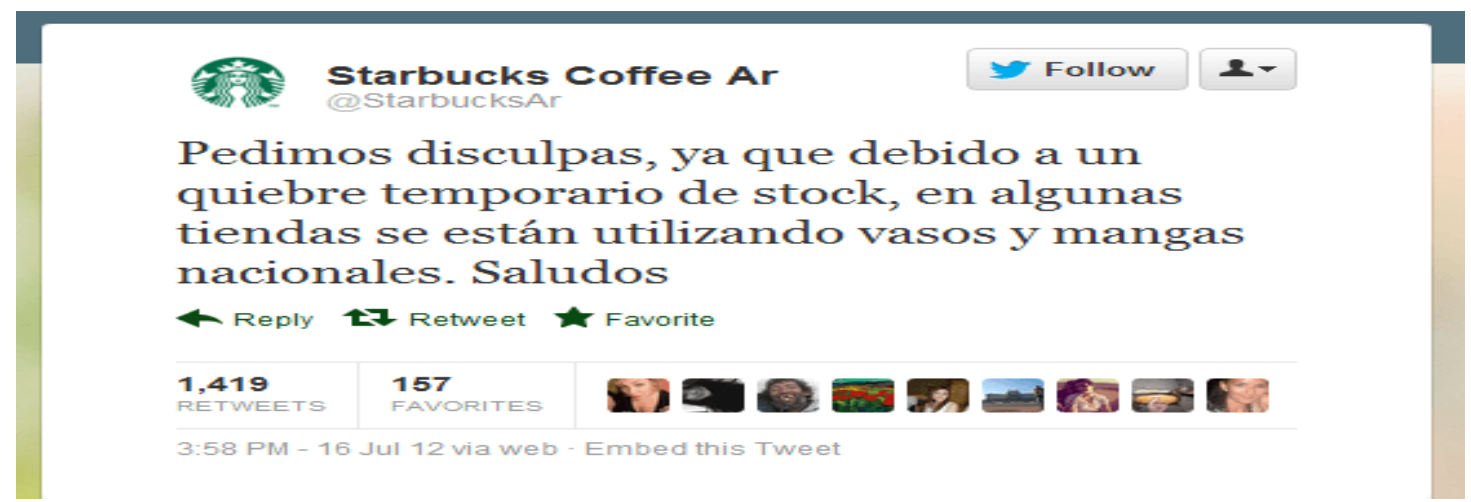

Şekil 3: Starbucks Firmasının Krize Neden Olan Sosyal Medya Paylaşımı (http://comtalks.com, 2017).

Danone: Danone hakkında 2005 yılında bir internet sitesinde kaynağı belli olmayan bir yazı paylaşıldı. $\mathrm{Bu}$ yazının içeriği, Türkiye'ye pazarlanan ürünlerin çocuk gelişimi açısından zararlı maddeler içerdiği yönündeydi. Bu haber sosyal medya içerisinde ve mail yoluyla hızla yayıldı. Danone yetkililerinin ilk başlarda fazla önemsemedikleri bu durum satışların düşmesiyle büyük bir olaya dönüştüğü anlaşılmıştır. Daha sonra firma yetkilileri bu yazıyı paylaştığı söylenen kişiye ulaşarak kendisinden imzalı bir açıklama istenmiştir. Ancak bu kişinin olaylardan haberi olmadığı anlaşılınca yazının başka bir kişinin ağzından yazılıp paylaşıldığı anlaşılmıştır. Firma yetkilileri olayı yatıştımak için üretim bölgelerinde uzman kişilerce üretimin uygun koşullarda ve zararlı olmayan maddelerle yapıldığını kanıtlacayak çeşitli faaliyetlerde bulunmuştur. Son olarak sosyal medya üzerinden, çıkan asılsız haberlerin gerçeğini yansıtmadığı açıklamaları yapılmıştır.

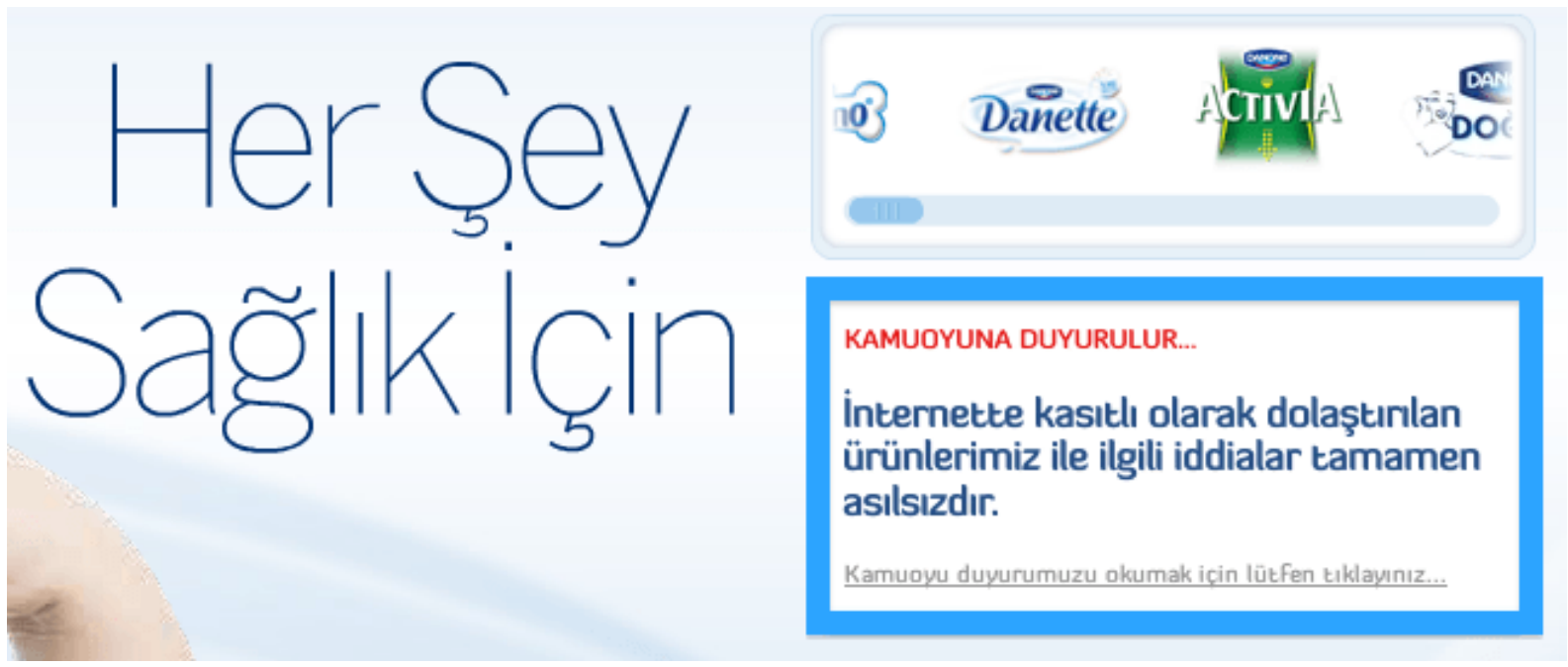

Şekil 4: Danone Firmasının, Yaşadığı Sosyal Medya Krizini Yönetmek İçin Kullandığı Sosyal Medya Paylaşımı (http://comtalks.com, 2011)

Nestle: Nestle firması, bazı ürünlerinde orangutanların doğal yaşam alanlarında bulunan palmiye yağını kullanırken, çevresinde yaşayan orangutanlara zarar vermesi nedeniyle Greenpeace ile aralarında bir gerilim oluşmuştur. Greenpeace, bu olayı protesto etmek 


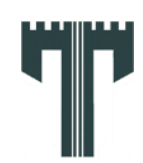

Gastroia: Journal of Gastronomy and Travel Research, Vol. 3, Issue 4 (Özel Sayı), 612-623, 2019

Yiyecek İ̧ecek İşletmelerinde Sosyal Medya Kullanımı ve Kriz Yönetimi Hülya TAŞTAN, Enes GÜRHANI

amacıyla Kit-Kat'ın ünlü sloganı olan 'have a break' sloganını kullanarak, sosyla medya üzerinden çektikleri kısa videoları ve yazıları paylaşıp Nestle'nin sosyal medya krizi yaşamasına neden olmuştur. Videoların sosyal medya üzerinden kaldırılmasına rağmen, Greenpeace takipcilerinden bu videolarını yaymalarını istemesi üzerine olay hızlı bir şekilde büyümüş ve Nestle firmasının CEO'su, Greenpeace ile düzenli görüşmeler sağlayarak üretimlerinde ormanlara zarar verecek herahangi bir eylemden kaçınacaklarını bildirmiştir.

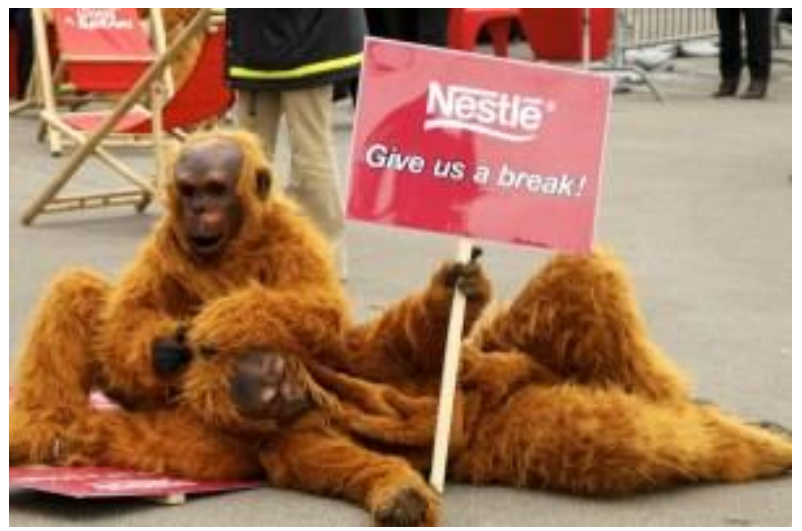

Şekil 5: Greenpeace’in Nestle Firmasına Karşı Yaptığı Tepki Eylemi (http://comtalks.com, 2013)

KFC: Bir diğer kriz haberi ise ünlü fast food devlerinden biri olan KFC'nin başına gelmiştir. KFC işletmesi bünyesinde çalışan 3 kişi mutfakta bulaşık yıkamak için kullanılan geniş bir evyeyi su ile doldurarak banyo yaptıkları görüntüleri sosyal medya üzerinde paylaşması üzerine kriz çı̆̆ gibi büyümüştür. Olayın çok fazla tepki alması üzerine KFC işletmesi yetkilileri yaşanan hadisenin yerini tespit ederek çalışanların işlerine son vermişlerdir.
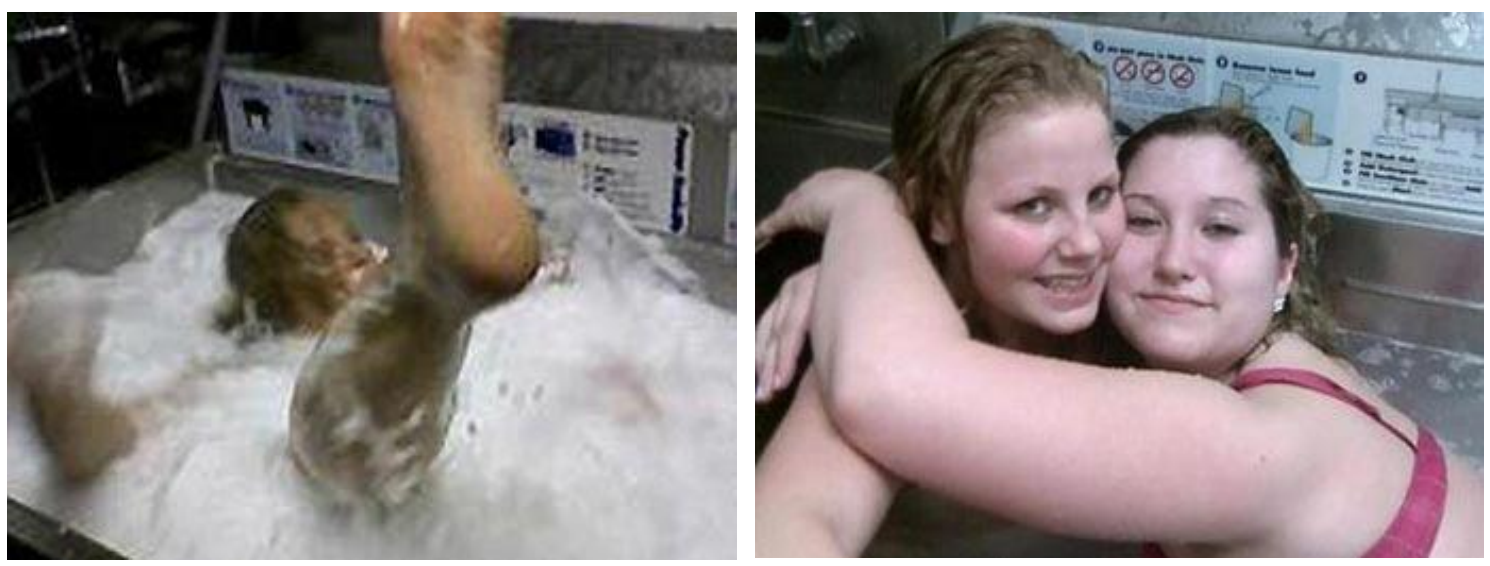

Şekil 6: KFC Firmasının Krize Neden Olan Sosyal Medya Paylaşımları (www.mynet.com, 2008)

Burger King: 2008 yılında ABD'nin Ohio eyaletinde çıkan sosyal medya krizi ise şu şekilde gerçekleşmiştir. Burger King'in bir şubesinde bulaşıkların yıkandığı evyeyi su ile doldurup içerisinde banyo yapan bir çalışan, bu görüntüleri video olarak Myspace'e 
Yiyecek İ̧ecek İsletmelerinde Sosyal Medya Kullanımı ve Kriz Yönetimi Hülya TAŞTAN, Enes GÜRHANI

yükleyerek bir krize sebebiyet vermiştir. Bunun üzerine şubeye sağlik müfettişleri tarafından bir baskın düzenlenmiştir. Müfettişlere durumu açıklayan yetkililer durumun farkında olduklarını ve çalışanın işine son verildiğini ifade etmişlerdir (prezi.com, 2013).

Domino's Pizza: Domino's Pizza'da çalışan 2 personelin sipariş hazırlarken çektikleri videoyu sosyal medya üzerinden paylaşmaları üzerine işletme çok ağır bir krizin içine çekilmiştir. Sandviç siparişi hazırlayan bir personel rendelenmiş kaşarlar ile burnunu karıştıp, salamları ise vücudunun çeşitli yerlerine sürerek sandivicin içerisine koyduğunun görüntüleri sosyal medyada paylaşılması üzerine firma yetkilileri hemen olaya el atarak krizi yönetmek için şu yöntemleri izlemiştir; (http://www.digitalfabrika.com, 2012)

$>$ Videoyu çeken ve sandivici hazırlayan çalışan işten çıkarılarak adlarına dava açılmıştır.

> Firma, sosyal medya üzerinden bir özür yazısı paylaşarak twitter üzerindeki linklerin kaldırılmasını istedi.

> Firma, müşterilerle daha yakından ilgilebilecekleri bir@dpzinfo hesabı açarak daha kontrollü bir kriz yönetimi hedeflemişlerdir.

$>$ Dominosun ABD yöneticisi Patrick Doyle tarafından tekrar bir özür mesaj1 yayınlanarak hatanın kesin çözüme kavuşturulduğunu ifade etmiştir.

\section{SONUÇ VE DEĞERLENDİRME}

Günümüzde teknolojinin hızla gelişmesiyle beraber çoğu işletme gibi yiyecek ve içecek işletmeleri de bu teknolojiye ayak uydurarak, toplumun ihtiyaçlarını en iyi şekilde karşılayacakları dijital pazarda yerlerini almaya başlamışlardır. Bu sayede işletmeler bir yandan ürünlerinin reklamlarını düşük maliyetlerle yaparken bir yandan da müşterilerden geri bildirim sağlayarak, ürünleri hakkındaki artı ve eksi yönleri tespit edebilmektedir.

Yiyecek ve içecek işletmeleri her ne kadar bu işi uzmanlara bıraksa da teknoloji sadece iyi amaçlı insanlar için gelişmemektedir. Aynı zamanda, zararlı yazılımlar da teknolojinin gelişmesi ile birlikte kötü amaçlı insanların kullanımına sunulmaktadır. Zararlı yazılımları kullanarak yiyecek ve içecek işletmelerinin sosyal medya hesaplarını hackleyen insanların oluşturduğu veya işletmelerin kendi personellerinin yaptıkları hatalardan dolayı oluşan büyük krizleri yönetmek çoğunlukla yöneticilere düşmektedir. Bu bağlamda, yiyecek içecek işletmelerinin yaşadıkları olumsuz olayların nasıl sosyal medyada yayılarak kriz haline gelebildiğini ve bu krizlerin sosyal medya üzerinden nasıl yönetildiğini araştırmak amacıyla yapılan bu çalışm ile sosyal medya ya yansımış yedi yiyecek içecek işletmesinin karşılaştığ1 kriz incelenmiştir. Yapılan örnek olay incelemelirinin sonucunda bu işletmelerin üç tanesi çalışanlarının yaptığı tiksindirici sosyal medya paylaşımları yüzünden krize maruz kalmıştır. Bu üç işletmenin tamamı krize sebep olan çalışanların işine son vermiştir ve bunuı sosyal medya hesaplarından duyurmuşlardır. Hatta bunlardan biri çalışanın işine son vermekle kalmayıp söz konusu çalışanlara dava açmıştır. İncelenen işletmelerin ikisi ise yine çalışanlarının yaptığı ve yanlış anlaşılan paylaşımlar yüzünden sosyal medya da bir krizle karşılaşmışlardır. Bu iki işletmede sosyal medya hesapları üzerinden müşterilerinden özür dilyerek gerekli önlemlerin alındığını belirtmişlerdir. Son olarak iki işletme ise işletme dışı kişilerin sosyal medyada yaptıkları paylaşımlar yüzünden 
bir kriz yaşamışlardır. Bu iki işletme ise sosyal medya üzerinden hem özür dileyerek hem de krize sebep olan kişi ve kurumlarla iletişime geçerek krizi yönetme yoluna gitmişlerdir.

İncelenen işletmeler, krizleri yöneten tecrübeli yöneticilere sahip olsalar da hem maddi olarak hem de manevi olarak zarara uğramaktan kaçamadıkları görülmüştür. Bu zararın en aza indirgenmesi için de yöneticiler hataları kabullenerek karşı tarafın zararını karşılamış veya ürünlerinde kampanya çalışması yapmak gibi çalışmalar yapmışlardır. Ancak, özellikle çalışanlarının paylaşımları yüzünden kriz yaşayan işverenler işgörenlerine karşı daha olumlu davranışlar göstermeli ve sadakatlerini arttıracak çeşitli uygulamalar yaparak bu tarz sorunların oluşumunu önleyebilmelidir. Diğer yandan işgörenler ise emek verdikleri iş yerleri ve hizmet verdikleri müşterilerin sağlığı için daha dikkatli davranlalı ve eğer yaşan bir sıkıntı var ise bunu direk yöneticileri ile çözmeye çalışmalıdırlar. Bu sayede hem işletmeler hem çalışanlar hem de müşteriler mümkün olan en iyi şekilde hayatlarına devam edebileceklerdir.

\section{KAYNAKÇA}

Akgöz, E. (2007). Kriz Ortamında Turizm İşletmelerinin Rekabet Aracı Olarak İtibar Yönetimi. Journal of Azerbaijani Studies, 162.

Aslan , E. Ş. (2016). Markaların Kriz Dönemlerinde Sosyal Medya Kullanım Stratejileri: Gezi Parkı Olayları Sürecinde Twitter Üzerine Bir İnceleme. Gümüşhane Üniversitesi İletişim Fakültesi Elektronik Dergisi, 517.

Asunakutlu, T., Safran, B., \& Tosun , E. (2003). Kriz Yönetimi Üzerine Bir Araştırma. Dokuz Eylül Üniversitesi Sosyal Bilimler Enstitüsü Dergisi, 150.

Ataman, G. (2001). Kriz Yönetimi. G. Ataman içinde, İşletme Yönetimi, Temel Kavramlar ve Yeni Yaklaşımlar. (s. 256). İstanbul: Türkmen Kitabevi.

Aydın, B. (2016). SOSYAL MEDYADA RESTORAN IMAJI: TRIPADVISOR ÖRNEĞİ. Disiplinlerarası Akademik Turizm Dergisi, 1.

Bat, M., \& Turan Yurtseven, Ç. (2014). SOSYAL MEDYADA KURUMSAL KRİZ YÖNETIMİ: ONUR AİR ÖRNEĞİ. Gümüşhane Üniversitesi İletişim Fakültesi Elektronik Dergisi, 205.

Beliktay, A. (2013). Sosyal Medyada Marka Yönetimine İletişim Öğrencilerin Algısı. Anadolu Üniversitesi İletişim Bilimleri Fakültesi, 11.

Bilgin, H. F. (1998). Turizmde Risk ve Kriz. 1. Turizm Şurası (s. 51). Ankara: Kültür ve Turizm Bakanlığı.

Can, H. (1997). Kriz Yönetim Sürecinin Aşamaları. H. Can, Ö. Aşan Azizoğlu, \& E. M. Aydın içinde, Organizasyon ve Yönetim (s. 302). Ankara: Siyasal Kitapevi.

Capatani, A., Micu, A., Micu, A. E., Bouzaabia, R., \& Bouzaabia, O. (2018). Country-based comparison of accommodation brands in social media: An fsQCA approach. Journal of Business Research, 30.

Capatina, A., Micu, A., Micu, A. E., Bouzaabia, R., \& Bouzaabia, O. (2017). Country-based comparison of accommodation brands in social media: ancountry-based comparison of accommodation brands in social media: An Fsqca Approach. Journal Of Business Research, 18 . 
Demirel, S. (2013, Ocak). SOSYAL MEDYA VE MÜŞTERİ İLIŞKILLERİ YÖNETİMİ. Ulusal Tez Merkezi, 27-28.

Demirtaş, H. (2000). Kriz Yönetimi. DergiPark, 368.

Farajova, T. (2017, Mayis 11). http://www.pazarlama30.com. http://www.pazarlama30.com: http://www.pazarlama30.com/wpcontent/uploads/2017/06/SOSYAL_MEDYADA_MARKALAR_ANKET\%C4\%B0_ANAL\%C 4\%B0Z\%C4\%B0c6d927a5f83a2e4f409990f82e956d9f6483e4f8.pdf adresinden alınd1

Gülmez, M. (2011). Word of mouth marketing applications on the internet . İnternet Uygulamaları ve Yönetim Dergisi, 31.

Gündüz, U., \& Engin, Y. (2016). Sosyal Medya ve Dijital Kimlik Olgusu. A. Büyükaslan, \& A. M. Kırık içinde, Sosyal Medya Araştırmaları 3 (s. 43-60). Konya: Çizgi Kitapevi.

Hatipoğlu, B. H. (2009, Temmuz 25). Sosyal Medya ve Ticaret Hayatına Etkileri. www.cioclub.net: http://www.cio-club.net/Makaleler/PDF/E-Ticaret adresinden alınd1

Hossein, N., Amidi, A., Jusoh, Y. Y., Moghadas, S., Aziz, Y. A., \& Sohrabinezhadtalemi, R. (2015). Review of Social Media Potential on Knowledge Sharing and Collaboration in Tourism Industry. Procedia - Social and Behavioral Sciences, 120-125.

http://comtalks.com. (2011, Şubat 1). http://comtalks.com: http://comtalks.com/2011/02/01/yeninesil-kriz-yonetimi/ adresinden alındı

http://comtalks.com. $\quad(2013, \quad$ Eylül $\quad 17) . \quad$ http://comtalks.com: http://comtalks.com/2013/09/17/dikkat-sosyal-medya-krizi-cikabilir/ adresinden alınd1

http://comtalks.com. $\quad(2017, \quad$ Eylül http://comtalks.com: http://comtalks.com/2013/09/17/dikkat-sosyal-medya-krizi-cikabilir/ adresinden alındı

http://www.digitalfabrika.com. (2012, Şubat 28). http://www.digitalfabrika.com: http://www.digitalfabrika.com/blog/vaka-analizi-dominos-pizza-sosyal-medya-krizi/ adresinden alınd 1

Karaköse, T. (2007). ÖRGÜTLER VE KRİZ YÖNETIMII. Uluslararası Hakemli Sosyal Bilimler E-Dergisi, 13.

Khodarahmi, E. (2009). Crisis Management, Disaster Prevention and Management. Disaster Prevention and Management: An International Journal, 527.

Leung, D., Law, R., Hoof, H., \& Buhalis, D. (2013). Social Media in Tourism and Hospitality: A Literature Review. Journal of Travel \& Tourism Marketing, 3-22.

Mathews, S., Bianchi, C., Perks, K. J., Healy, M., \& Wickramasekara, R. (2016). Internet marketing capabilities and international market growth. International Business Review, 820.

Mayfield, A. (2010, Şubat 2). e-book. iCrossing: http://www.icrossing.co.uk/fileadmin/uploads/eBooks/What_is_Social_Media_iCrossing_ebook .pdf adresinden alınd1

medyasyon.wordpress.com. (2012, May1s 5). medyasyon.wordpress.com: https://medyasyon.wordpress.com/2012/05/31/en-buyuk-sosyal-medya-krizleri-ve-markalaramaliyeti/ adresinden alınd 1

Oğuz, B. (2012). Sosyal Medya Dilinin Görüntüsel Gösterge Boyutu ve Bunun Dile. Turkish Studies, 1159. 
Öztürk, A. (2010). Marka İletişiminin Kriz Dönemlerinde İşletme Performansına Etkisi ve Hazır Giyim İşletmeleri Üzerine Bir Araştırma. Sosyal Bilimler Meslek Yüksek Okulu Dergisi, 2.

prezi.com. (2013, Mayı 19). prezi.com: https://prezi.com/ksgnrkgekl3p/burger-king-krizleri/ adresinden alınd 1

Sarışık, M., \& Özbay, G. (2012). Elektronik Ağızdan Ağıza İletişim ve Turizm Endüstrisindeki Uygulamalara İlişkin Bir Yazın İncelemesi. Uluslararası Yönetim İktisat ve İşletme Dergisi, 122.

Sezgin, F. (2003). Kriz Yönetimi. Manas Sosyal Bilimler Dergisi, 194.

socialbakers. $\quad(2018, \quad 12 \quad$ 15). socialbakers. $\quad 12$ socialbakers: https://www.socialbakers.com/statistics/twitter/profiles/turkey/brands/retail-food/ adresinden alınd 1

socialbakers. $\quad(2018, \quad 12 \quad$ 15). SocialBakers. $\quad$ SocialBakers: https://www.socialbakers.com/statistics/twitter/profiles/turkey/brands/retail-food/ adresinden alınd 1

Sotiriadis , M. D. (2016). Sharing tourism experiences in social media. Emerald Insight, 179-225.

Sü Eröz, S., \& Doğdubay, M. (2012). Turistik Ürün Tercihinde Sosyal Medyanın Rolü ve Etik İlişkisi. Dokuz Eylül Üniversitesi İktisadi ve İdari Bilimler Fakültesi Dergisi, 27.

techcrunch.com. (2011, Haziran 10). techcrunch.com: https://techcrunch.com/2011/07/05/entenmanns-hashtag-surfing-fails-hard-with-notguilty-tweet/ adresinden alınd 1

Track, P. B. (1994). Kriz Zamanı Yönetim. P. B. Track içinde, Kriz Zamanı Yönetim (s. 25). İstanbul: İlgi Yayıncılık.

Vural, B. Z., \& Bat, M. (2010). YENİ BİR İLETIŞiM ORTAMI OLARAK SOSYAL MEDYA: EGE ÜNIVERSITESİ İLETIŞSiM. Yaşar Üniversitesi Dergisi.

Ward, C. (2011). Social media and crisis communication : are organizations using social media in times of crisis? Ball State Theses and Dissertations , 3.

Weber, M. (2009). Marketing To The Social Web: How Digital Customer. New Jersey: John Willey\&Sons Inc.

www.mynet.com. (2008, Aralik 12). www.mynet.com: https://www.mynet.com/kfcde-dusskandali-110100362256 adresinden alındı

Yeni Mesaj. (2018, 12 3). Yeni Mesaj. Yeni Mesaj Web Sitesi: http://www.yenimesaj.com.tr/2018internet-ve-sosyal-medya-istatistikleri-H1308335.htm adresinden alınd1

Zeng, B., \& Gerritsen, R. (2014). What do we know about social media in tourism? A review. Tourism Management Perspectives, 27-36. 